\title{
Performance Analysis of Single Glazed Solar PVT Air Collector in the Climatic Condition of NE India ${ }^{\dagger}$
}

\author{
Biplab Das 1,2,*, Behnaz Rezaie 1, Prabhakar Jha ${ }^{2}$ and Rajat Gupta ${ }^{2}$ \\ 1 College of Engineering, University of Idaho, Moscow, ID 83844-0902, USA; rezaie@uidaho.edu \\ 2 Department of Mechanical Engineering, National Institute of Technology Silchar, Assam-788010, India; \\ jhaprabhakar963@gmail.com (P.J.); r.guptanitsri@gmail.com (R.G.) \\ * Correspondence: biplab.2kmech@gmail.com; Tel.: +91-9402168938; Fax: +91-3842224797 \\ + Presented at the 4th International Electronic Conference on Entropy and Its Applications, \\ 21 November-1 December 2017; Available online: http://sciforum.net/conference/ecea-4.
}

Published: 20 November 2017

\begin{abstract}
With the rapid depletion of fossils fuels, opportunities for renewable energy including solar energy are endless. The efficiency of photovoltaic cells to convert the solar energy into electricity drops with the rise in temperature due to increased resistance. Thus, improving the efficiency by lowering the thermal resistance and allowing the cooling fluid (air/water) to flow through photovoltaic thermal (PVT) system is an attractive option. Climate condition based performance of any PVT system varies location wise, and cannot be generalized. Silchar is a city located in Himalayan region has tropical climatic conditions and most of its decentralized villages are out of grid connectivity. Unlike other metro cities of India, PVT will play a critical role for the development of theses villages. Keeping this in mind an attempt is made in the present study to perform an analysis of single glazed solar PVT air collector on the basis of energy and exergy for the climatic conditions of Silchar, India. An analytical model is developed to evaluate the hourly variation of PV cell temperature, cell efficiency, useful thermal heat gain, useful electrical heat gain, energy efficiency and exergy efficiency PVT system. Results depict that efficiency of PV cell decreases with the increase in temperature, and a maximum efficiency of $14.6 \%$ for the PV module is found. Out of total useful heat output, the thermal heat output contributes $60.7 \%$ while the rest is electrical heat output. Further, magnitude of the heat output is found to increase with the solar radiation and the maximum observed solar ray at around 12:30 $\mathrm{h}$. Trend of both energy and exergy efficiency is similar except the magnitude. Maximum efficiency observed to be $83 \%$ and $16.5 \%$ for energy and exergy, respectively.
\end{abstract}

Keywords: PVT air system; cell efficiency; cell temperature; useful thermal energy; useful electrical energy; exergy

\section{Introduction}

Energy plays a vital role to fulfil the daily needs of every sector like industrial, agricultural, medical, transportation, household, etc. For decades, fossil fuels are one of the primary sources used for energy generation. The rapid growth of population coupled with modernization and urbanization lay to the increasing demand of energy leading to aggressive consumption of fossil fuels. In such a scenario, researchers of the present world have given more attention on efficient extraction and optimum utilization of all forms of energy which includes both renewable and non-renewable sources. Non-renewable sources of energy are considered as environment-friendly compared to its other counterparts as it keeps balance with the ecosystem by contributing negligible greenhouse 
gases [1]. For developing countries like India, renewable energy technology is providing a platform to reduce the burden on the import of highly depleting fossil fuels.

Solar energy is abundant in nature and application of the solar energy technology is rapidly increasing, especially during the last few decades. Most widely adopted technology for extraction of solar energy is through the use of photovoltaic cell (PV) for generation of electricity and use of solar thermal collector for direct and indirect heating processes. Solar energy conversion efficiency of PV cell is relatively low, and it further reduces with the increase in solar radiation. However, with the incorporation of solar collector (air/water) with PV cell (hereafter refer as PVT system) enhancement in output useful energy can be achieved by enhancing the electrical efficiency by lowering the temperature of the back surface of the PV cell. Over the past few years, multiple attempts are being aggressively made to increase the overall energy gain from the photovoltaic thermal system by incorporating various designs and the modified parameters.

Bhargava et al. [2] evaluated the performance of PVT air collector whose fraction of absorber plate was covered by the solar cell on single pass air heater and observed that the solar cell efficiency and thermal efficiency increases with the increase in mass flow rate of air. Sopian [3] studied the effect of collector depth, packing factor and mass flow rate for the single pass and double pass air collector. It was observed that the cell efficiency was higher in case of double pass air collector while the overall efficiency was found as 40-45\%. Garg and Adhikari [4] simulated the glazed PVT air collector model for single and double glass configuration and observed that thermal energy gain increases for with the increase in mass flow rate, cell density, and collector length. Further, they concluded that double glass configuration is less affected by the single glass due to high depth of air duct. Hegazy [5] numerically investigated the single and double PVT air collector with four configurations namely flow of air above, below and the two sides of absorber plate and concluded that the flow of air above the absorber plate yields highest overall efficiency. Othman et al. [6] developed a single pass PVT module air collector by placing a del-grooved absorber plate. The performance of the system was compared with and without del-grooved absorber plate and it was observed that with del-grooved absorber plate the thermal and electrical efficiency of the PVT air collector was enhanced. Further, it was also concluded that the overall efficiency increased with the increase in radiation intensity and mass flow rate of air. Kim and Kim [7] made a comparison of electrical and thermal properties of the glazed and unglazed type PVT collector suggested that maximum overall efficiency of the glazed type is $12.6 \%$ higher than its counterpart. Further, concluded that the electrical properties of the system depend upon the incident solar radiation and inlet fluid temperature. Tonui and Tripanagnostopoulos [8] developed and experimentally analyzed the glazed and unglazed PVT air collector by suspending a thin metal sheet and placing a fin on the back surface of the air duct to remove the hot air effectively. It was found that the additional attachment enhances the thermal properties of the system. However, the glazed system was found better than the unglazed system. Raman and Tiwari [9] experimentally analysed the performance of glazed type PVT air collector for the climatic condition of four cities of India namely Srinagar, Mumbai, Jodhpur and New Delhi. It was found that Jodhpur has highest thermal energy and exergy gain as solar radiation of Jodhpur is highest and cost $/ \mathrm{kWh}$ for climate conditions of Jodhpur is also most economical. Dubey et al. [10] studied the electrical efficiency of glazed PVT air collector for the glass to glass and glass to tedlar with and without air duct. It was found from the analytical study that glass to glass PV module yields highest electrical efficiency. However, the electrical efficiency is highest with the presence of air duct. Farshchimonfared et al. [11] connected PVT air collector with the distribution system of air of the residential building. It was observed that the smaller collector depth offered good performance for large temperature difference; but, the design was very sensitive to changes in the ratio of collector area and mass flow rate of air. Sarhaddi et al. [12] developed a numerical model of PVT air collector and suggested that the exergy of the system first increased and then decreased with an increased mass flow rate and incident solar radiation. Agrawal and Tiwari [13] studied four different type of configuration for glazed hybrid microchannel and concluded that the overall annual thermal and combined efficiency increases by $70.62 \%$ and $60.19 \%$ respectively. Hussain et al. [14] proposed an air collector with aluminum honeycomb which act as a heat exchanger. The performance of the PVT 
collector assessed with and without aluminum honeycomb. It was revealed from the study that thermal efficiency enhanced by the presence of honeycomb with the PVT collector. Khelifa et al. [15] did a numerical investigation of PVT collector with the help of ANSYS software where air was used as heat carrier and validated the result with the literature on experimental analysis. The study mainly described the heat transfer phenomena of PVT collector. Yang et al. [16] did an experimental analysis of PVT air collector with two inlet configuration and compared its performances with one inlet configuration. It was found from the study that the thermal properties of two inlet system are better than one inlet system. Pauly et al. [17] did a numerical investigation of HPVT system by introducing a novel design and validated the result with the literature. The overall performance of the HPVT system enhanced by $20 \%$, when related to conventional type HPVT system. Mojumder et al. [18] proposed PV/T collector (unglazed) with fins and analyzed its performance experimentally. The purposed system was studied by varying the numbers of fins and flow rate of air from 0 to 4 and $0.02 \mathrm{~kg} / \mathrm{s}$ to $0.14 \mathrm{~kg} / \mathrm{s}$. It was found that the thermal and PV efficiency was maximum for four numbers of fins. Dimri et al. [19] integrated thermoelectric cooler with PV/T collector and compared its performance with the semitransparent PV/T collector. It was found from the study that the electrical and exergy gain of proposed system was higher than the semitransparent PVT air collector. Ooshaksaraei et al. [20] conducted an experimental study on bifacial PVT air collector with different configurations. The performance of the system was studied with single and double path flow design of air collector and concluded that single path design yields high electrical efficiency while double path design yields high thermal energy. Slimani et al. [21] compared four types of solar cell configurations, namely PV module, conventional HPVT, glazed HPVT and double pass HPVT system in the climatic condition of Algiers, Algeria. At constant flow of air, the daily average energy efficiency for double pass HPVT system was found as $74 \%$ which is higher than the other three configurations.

The second law of thermodynamics tells that entropy generation is always coupled with heat transfer. And higher the amount of heat transfer higher the system will depart from the reversible limit. Therefore, to unveil the viability of performance enhancement of any thermodynamic system, it is very much essential to perform the exergy analysis along with the energy analysis. Kamthania et al. [22] conducted an analytical study for semi-transparent hybrid PVT double pass air collector and made detailed comparisons with single pass air collector and observed that double air collector has a certain amount of advantages over single pass air collector. Agarwal and Tiwari [23] performed an exergoeconomic analysis for the climatic condition of New Delhi, India and observed that the overall thermal and energy gain from glazed PVT module air collector was found as $1252.0 \mathrm{kWh}$ and $289.5 \mathrm{kWh}$, respectively, with the net electrical saving of $234.7 \mathrm{kWh}$. A detail combined energy and exergy analysis of solar PVT system had been extended later on by Dubey and Tiwari [24] and Agarwal and Tiwari $[25,26]$. Recently, Bahrehmand et al. [27] studied the effect of length, depth of duct and fin of solar collector. The result obtained from the study suggested that fin plays an important role in order to obtain appreciable amount of thermal and exergy gain from the solar collector.

Pertinent literature reveals that a good number of attempts are being made in the last decades to unveil the possibilities to improve the efficiency of the PVT system. It is also seen that the performance of the PVT system highly depends on climatic conditions of the particular area. Few attempts are made to evaluate the performance of PVT system for different cities of India for various climatic conditions. Silchar located in the NE part of India, has got a tropical climate, unlike other cities of India, where tests of PVT system are already performed either experimentally or analytically. Use of solar power in the form of electricity through PV panel is getting popularity in this part of India, most of which are yet to get the grid connectivity. Further, because of tropical climate, Silchar has rain most of the months and has short dry season. Thus, seeing the practical relevance, to unveil the scope of PVT system, preliminary studies on PVT system for the climatic condition of Silchar is utmost important. Keeping these points in mind it is attempted in the present work to evaluate the performance of PVT system analytically. 


\section{Methodology}

Thermal analysis for a single glazed single pass PVT air system with PV module of monocrystalline silicon solar cells through energy and exergy analysis has been attempted in the present study. The key output parameters like the solar cell temperature $\left(T_{c}\right)$, the outlet air temperature $\left(T_{f o}\right)$, the useful heat gain $(Q)$, the temperature dependent electrical efficiency $(\eta)$, and the exergy efficiency $\left(\eta_{e x}\right)$ are expressed applying the energy and exergy balance at the various section of the PVT system. In order to write the energy and exergy balance equations, following assumptions are made:

$>$ Heat transfer process is one dimensional.

> The heat capacity of PVT collector system is negligible.

$>$ The system is in quasi-steady state.

$>$ The ohmic and recombination losses in the solar cell are negligible.

\subsection{Energy Analysis}

Applying the energy balance for solar cells of PV module, i.e., solar energy available on PV module is the summation of the overall heat loss from top surface of the cell, the rate of heat transfer from cell to back surface of the tedlar, and the rate electric energy produced $[25,26]$. This will give the PV cell temperature $\left(T_{c}\right)$ :

$$
T_{c}=\frac{\left\lfloor\tau_{g}\left\{\alpha_{c} \beta+\alpha_{T}(1-\beta)-\eta_{o} \beta\right\}\right\rfloor I(t)+U_{t c, a} T_{a}+U_{T} T_{b s}}{U_{t c, a}+U_{T}}
$$

Energy balance on the back surface of the tedlar give, the rate of heat transfer from the cell to back surface of tedlar is equals to the rate of heat transfer from back surface of the tedlar to flowing fluid $[25,26]$. Thus, back surface temperature of PV module $\left(T_{b s}\right)$ :

$$
T_{b s}=\frac{\left.h_{p 1} \mid \tau_{g}\left\{\alpha_{c} \beta+\alpha_{T}(1-\beta)\right\}-\eta \beta\right\rfloor I(t)+U_{t T} T_{a}+h_{T} T_{f i}}{U_{t T}+h_{T}}
$$

Energy balance for the working fluid flowing below the tedlar, i.e., the rate of heat transfer from the back surface of the tedlar to the flowing fluid is the summation of the heat gain by the flowing fluid and heat loss from the flowing fluid to the ambient $[25,26]$. Thus, the outlet fluid temperature of the collector $\left(T_{f o}\right)$ :

$$
T_{f o}=\left[\frac{(\alpha \tau)_{e f f} I(t)}{U_{L}}+T_{a}\right]\left[1-\exp \left(-\frac{w L U_{L}}{m_{f} C_{f}}\right)\right]+T_{f i} \exp \left(-\frac{w L U_{L}}{m_{f} C_{f}}\right)
$$

Useful thermal heat gain $\left(Q_{u}\right)[25,26]$ can be evaluated as,

where $K_{k}=\left[\frac{w L F_{R} U_{L}}{m_{f} C_{f}}\right]$.

$$
Q_{u}=\left[A F_{R}(\alpha \tau)_{e f f}\left\{\frac{1-\left(1-K_{k}\right)}{K_{k}}\right\}\right] I(t)-\left[A F_{R} U_{L}\left\{\frac{1-\left(1-K_{k}\right)}{K_{k}}\right\}\right]\left(T_{f i}-T_{a}\right)
$$

Temperature dependent electrical efficiency $[25,26]$ 


$$
\eta=\frac{\eta_{o}\left[1-\frac{\beta_{o} \tau_{g}\left[\alpha_{c} \beta+\alpha_{T}(1-\beta)\right] I(t)}{U_{t c, a}+U_{T}}\left\{1+\frac{U_{T} h_{p 1}}{h_{T}+U_{t T}}+\frac{U_{T} h_{T} h_{p 1} h_{p 2}}{\left(U_{T}+U_{t T}\right) U_{L}}\left(1-\frac{1-\exp \left(-X_{o}\right)}{X_{o}}\right)\right\}\right]}{1-\frac{\beta_{o} \eta_{o} \tau_{g} \alpha_{c} \beta I(t)}{U_{t c, a}+U_{T}}\left[1+\frac{U_{T} h_{p 1}}{h_{T} U_{t T}}+\frac{U_{T} h_{T} h_{p 1} h_{p 2}}{\left(U_{T}+U_{t T}\right) U_{L}}\left(1-\frac{1-\exp \left(-X_{o}\right)}{X_{o}}\right)\right]}
$$

where $X_{o}=\frac{w U_{L} L}{m_{f} C_{f}}$.

The rate of electrical energy gain $(\mathrm{W})$ of hybrid PVT air collectors can be evaluated by $[25,26]$

$$
E x_{\text {electrical }}=\eta I(t) A
$$

Instantaneous thermal efficiency $[25,26]$

$$
\eta_{i}=\frac{Q_{u}}{A_{m} I(t)}
$$

Or

$$
\eta_{i}=F_{R}\left[(\alpha \tau)-U_{L} \frac{T_{f i}-T_{a}}{I(t)}\right]
$$

Based on the first law of thermodynamics, the expression for overall thermal energy gain $\left(Q_{u, t o t a l}\right)$ :

$$
\sum Q_{u, \text { total }}=\sum Q_{u, \text { thermal }}+\frac{\sum Q_{u, \text { electrical }}}{\eta_{\text {power }}}
$$

In Equation (9) the reason for the use of electrical power generation efficiency $\left(40 \% \geq \eta_{\text {power }} \geq\right.$ $20 \%$ ) is to compensate the high grade electrical energy to equivalent low grade thermal energy.

\subsection{Exergy Analysis}

Exergy analysis is based on the second law of thermodynamics, which gives that the summation exergy inflow, exergy inflow and exergy destructed is zero $[25,26]$. This gives the overall exergy gain $\left(E x_{\text {out }}\right)$ is the summation of thermal and electrical exergy, and can be obtained

$$
\sum E x_{\text {out }}=\sum E x_{\text {thermal }}+\sum E x_{\text {electrical }}
$$

Total exergy inlet $\left(E x_{i n}\right)$ can estimated as [25,26],

$$
E x_{i n}==A I(t)\left[1-\frac{4}{3}\left(\frac{T_{a}}{T_{s}}\right)+\frac{1}{3}\left(\frac{T_{a}}{T_{s}}\right)^{4}\right]
$$

Total thermal exergy $\left(E x_{\text {thermal }}\right)$ can be obtained as [25,26],

$$
E x_{\text {thermal }}=Q_{U}\left[1-\frac{T_{a}+273}{T_{f o}+273}\right]
$$

The exergy efficiency $\left(\eta_{e x}\right)$ of the hybrid PVT air collector is defined as [25,26],

$$
\eta_{e x}=\left(\frac{E x_{\text {out }}}{E x_{\text {in }}}\right) \times 100
$$


Using Equations (1)-(13) and with the ambient and the solar radiation data as input, energy and exergy performance of PVT air system is obtained. A detail methodology is discussed next.

\section{Model Analysis}

\subsection{Physical Model of PVT System}

PVT system consists of photovoltaic (PV) system and a solar thermal system. In the present study a single glazed single pass conventional PVT air system considered and shown in Figure 1. It is assumed that the collector is fully covered by a single PV module of mono-crystalline silicon solar cells with an effective area of $0.61 \mathrm{~m}^{2}$. Area of the air duct is considered to be $0.54 \mathrm{~m} \times 1.12 \mathrm{~m}$ and an air gap of $0.005 \mathrm{~m}$ is assumed between the tedlar and absorber plate. Various layer of the PVT system as shown in Figure 1 are, single glass cover (glazing), module of mono-crystalline silicon solar cell, tedlar, absorber plate, insulation. Details of the thermal and optical properties of the PVT system are depicted in Table 1 [24-26].
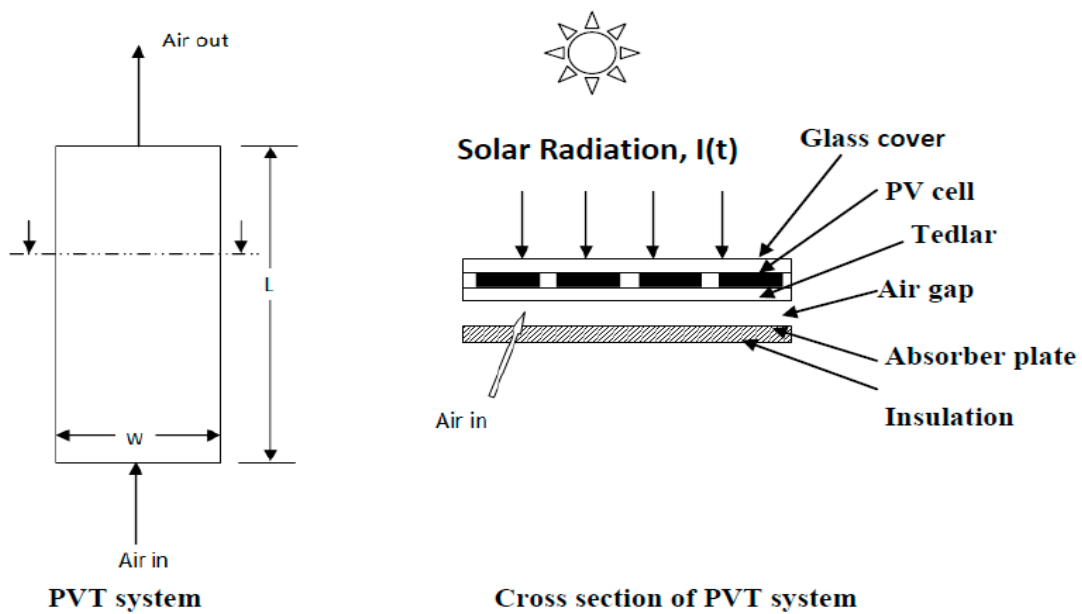

Figure 1. Schematic diagram of conventional PVT system [24-26].

Table 1. Thermal and optical properties of PVT system [24-26].

\begin{tabular}{cccc}
\hline Parameters & Value & Parameters & Value \\
\hline$A_{c}\left(\mathrm{~m}^{2}\right)$ & 0.61 & $h_{p 1}$ & 0.375 \\
$w(\mathrm{~m})$ & 0.54 & $h_{p 2}$ & 0.965 \\
$C_{f}(\mathrm{~J} / \mathrm{kgK})$ & 1012 & $U_{T}(\mathrm{~W} / \mathrm{mK})$ & 66 \\
$T_{0}\left({ }^{\circ} \mathrm{C}\right)$ & 25 & $U_{t}(\mathrm{~W} / \mathrm{mK})$ & 11.4 \\
$\alpha_{c}$ & 0.9 & $U_{t T}(\mathrm{~W} / \mathrm{mK})$ & 9.72 \\
$\beta_{o}$ & 0.0045 & $U_{L}(\mathrm{~W} / \mathrm{mK})$ & 5.62 \\
$\beta$ & 1 & $U_{t c, a}(\mathrm{~W} / \mathrm{mK})$ & 11.4 \\
$\eta_{o}$ & 0.15 & $\tau_{c}$ & 0.95 \\
$\tau_{g}$ & 0.95 & $\tau_{g}$ & 0.95 \\
$m_{f}(\mathrm{~kg} / \mathrm{s})$ & 0.0108 & $\alpha_{T}$ & 0.5 \\
$K_{g}(\mathrm{~W} / \mathrm{mK})$ & 1.1 & $\mathrm{FR}$ & 0.90 \\
$L_{g}(\mathrm{~m})$ & 0.003 & $h_{T}(\mathrm{~W} / \mathrm{mK})$ & 10.3 \\
$U_{t c f}(\mathrm{~W} / \mathrm{mK})$ & 4.03 & $\mathrm{~L}(\mathrm{~m})$ & 1.12 \\
$U_{f a}(\mathrm{~W} / \mathrm{mK})$ & 2.94 & $U_{L}(\mathrm{~W} / \mathrm{mK})$ & 9.83 \\
\hline
\end{tabular}




\subsection{Location of the Study}

Performance of the PVT system is studied for the climatic condition of Silchar located in NE India $\left(24.8333^{\circ} \mathrm{N}, 92.7789^{\circ} \mathrm{E}\right)$ for the day of 15 May 2017. In general climatic conditions of Silchar are hot and humid during the month of April to September; with an average temperature of $27^{\circ} \mathrm{C}$ and average humidity of $86 \%$. And during winter average temperature is $24^{\circ} \mathrm{C}$ and average humidity of $72 \%$. The hourly variations of solar radiation intensity and ambient temperature for the day of 15 May 2017 for the climatic condition of Silchar, Assam, India have been depicted in Figures 2 and 3 , respectively. It can be seen that the maximum intensity of both solar radiation and temperature is observed at around 11:00 a.m. to 1:00 a.m. This indicates the time zone, when maximum solar energy is available for extraction. During the testing day, magnitude of maximum solar radiation intensity and maximum ambient temperature observed to be $994 \mathrm{~W} / \mathrm{m}^{2}$ and $33.4{ }^{\circ} \mathrm{C}$, respectively. Further, considered air properties for the evaluation of the performance is tabulated in Table 2.

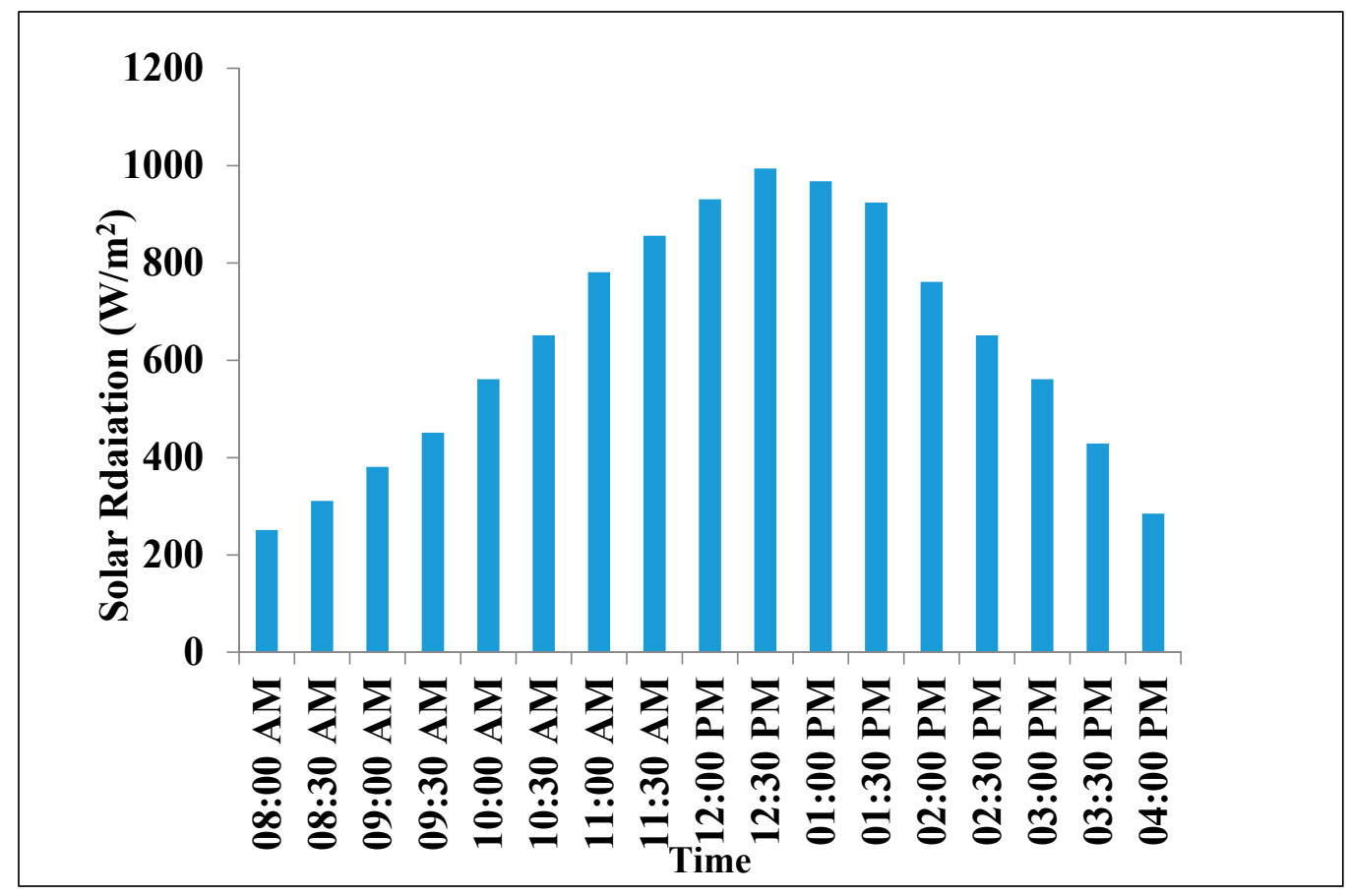

Figure 2. Variation of solar radiation during the day time of 15 May 2017 at Silchar.

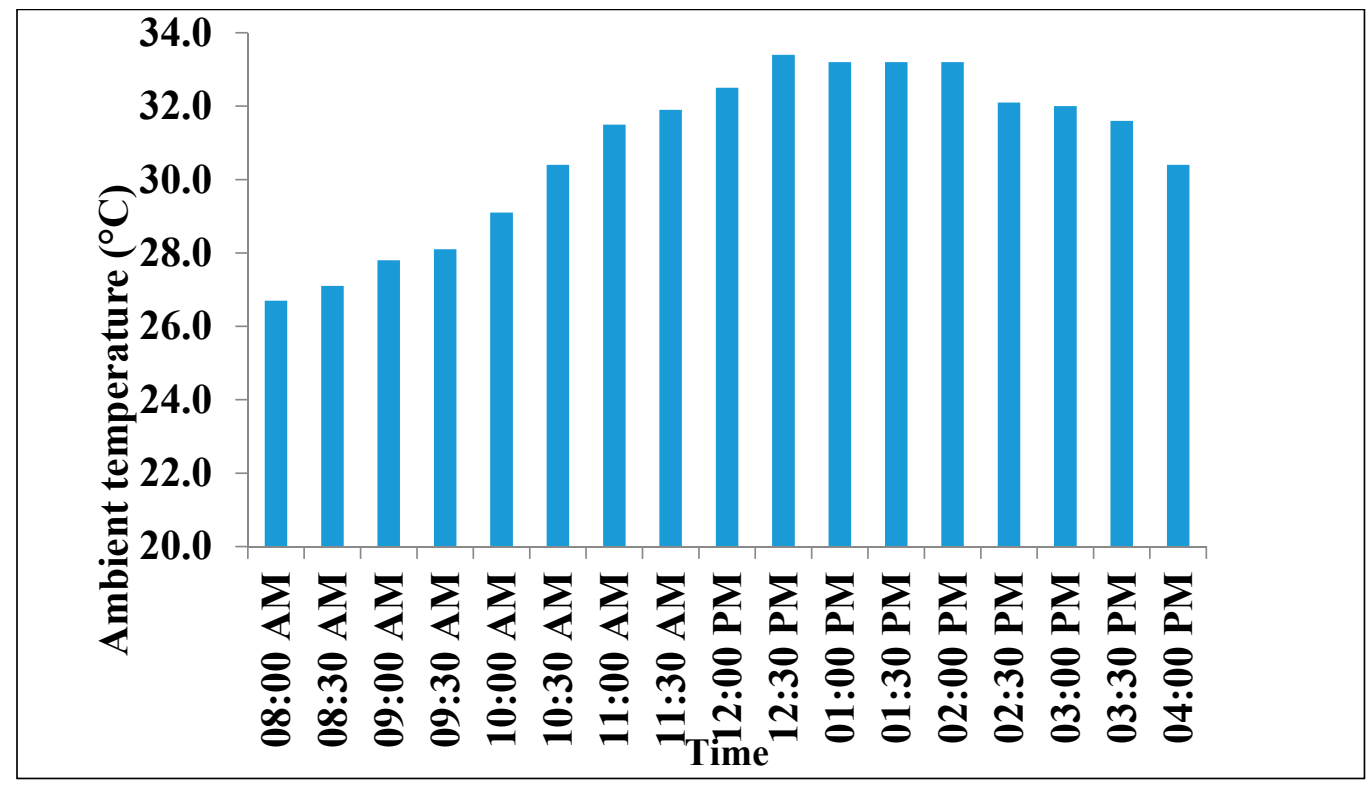

Figure 3. Variation of ambient temperature during the day time of 15 May 2017 at Silchar. 
Table 2. Environmental properties for the climatic condition of Silchar.

\begin{tabular}{cc}
\hline Parameters & Value \\
\hline$T_{0}\left({ }^{\circ} \mathrm{C}\right)$ & 25 \\
$h_{T}(\mathrm{~W} / \mathrm{m} \cdot \mathrm{K})$ & 10.3 \\
$T_{s}(\mathrm{~K})$ & 5778 \\
\hline
\end{tabular}

\section{Analysis}

The climatic data, namely solar radiation and ambient temperature of Silchar, for the considered day of the study is obtained from the Regional Testing Centre, NIT Silchar, India. In the present problem area of the collector is considered to be $0.61 \mathrm{~m}^{2}$, PV panel are made of monocrystalline silicon solar cell, and air is forced to pass through the absorber plate and the tedlar. The values of the PV cell temperature $\left(T_{c}\right)$, the back surface temperature of PV module $\left(T_{b s}\right)$, the outlet fluid temperature of the collector $\left(T_{f o}\right)$, the useful thermal heat gain $\left(Q_{u}\right)$, the temperature dependent electrical efficiency $(\eta)$, and the exergy efficiency $\left(\eta_{e x}\right)$ of the hybrid PVT air collector are obtained by inserting the climatic data and design data in Equations (1)-(13). Detail steps of the process are as follows:

(i) The back surface temperature of PV cell $\left(T_{b s}\right)$ is obtained by inserting the design data (Tables 1 and 2) and the climatic data of Silchar in Equation (1), and the same is used to obtain the PV cell temperature.

(ii) The PV cell temperature $\left(T_{c}\right)$ is obtained by inserting the climatic data and the back surface temperature of PV cell in Equation (1).

(iii) The magnitude of the useful heat gain $\left(Q_{u}\right)$ is obtained by inserting the inlet fluid temperature $\left(T_{f i}\right)$ and the climatic data in Equation (4).

(iv) The temperature dependent electrical efficiency $\left(\eta_{o}\right)$ is obtained by using the climatic data and the conversion efficiency of the PV cell $(\eta)$ in Equation (5).

(v) The instantaneous thermal efficiency $\left(\eta_{i}\right)$ is obtained by using the useful heat gain $\left(Q_{u}\right)$, the design data and the climatic data in Equation (7).

(vi) The exergy inlet $\left(E x_{i n}\right)$ is obtained by using the climatic data in Equation (11).

(vii) The exergy outlet $\left(E x_{\text {out }}\right)$ is obtained by using the climatic data and the overall useful heat gain $\left(Q_{u}\right)$ and electrical exergy $\left(E x_{\text {electric }}\right)$ in Equation (12).

(viii)Finally the exergy efficiency is obtained by using the exergy inlet $\left(E x_{i n}\right)$ and exergy outlet $\left(E x_{\text {out }}\right)$ in Equation (13).

Details results obtained by following above steps along with discussions are presented in the consecutive section.

\section{Results and Discussions}

Variation of photovoltaic (PV) cell temperature during the day time is unveiled in Figure 4. It is seen that with the increase in solar radiation and the corresponding ambient temperature, cell temperature is also increased; it attains its peak during noon and then starts decreasing. This may be because of higher insolation coupled with higher inlet temperature of working fluid. Thus, during noon time higher mass flow rate of working fluid need to pass through the PVT system. 


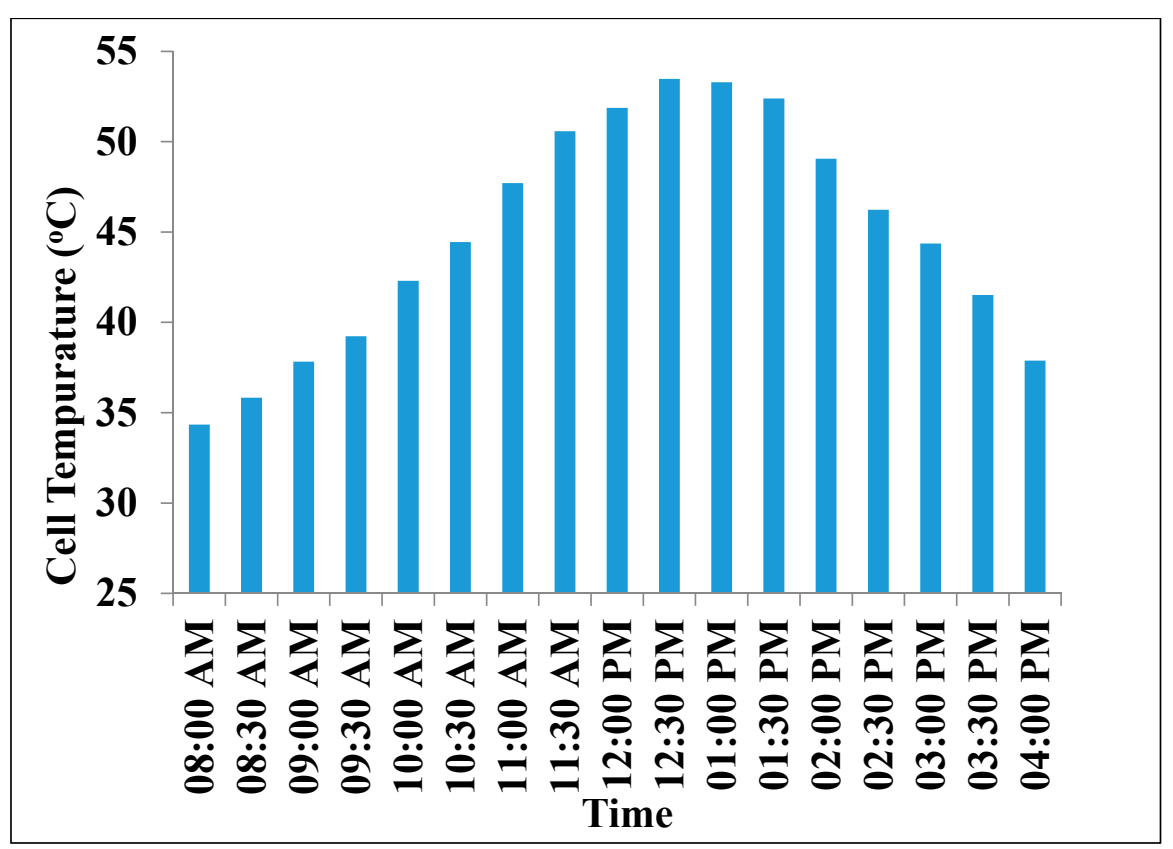

Figure 4. Variation of PV cell temperature of PVT system with time during the day, 15 May 2017.

Attention may now be turned to the variation of cell efficiency. Figure 5 represent the variation of cell efficiency during the day time. It is a well-known fact that the cell efficiency decreases with the increase in cell temperature, may be because of reduction in band gap of the semiconductor material at higher temperature. This is in agreement with earlier results [24-26]. In the present study, maximum efficiency of $14.6 \%$ is observed at the early morning and at the afternoon, when, the cell temperature is comparatively low, around $35{ }^{\circ} \mathrm{C}$. While lowest efficiency of $13.5 \%$ is obtained at highest cell temperature of $53^{\circ} \mathrm{C}$. Further, it can be concluded that, effect of reduction of cell efficiency on the overall performance of a PVT system may not be significant till cell temperature is within $50{ }^{\circ} \mathrm{C}$, since during the day time available solar energy for extraction is higher during the noon time. However, for higher solar power plant (e.g., $1 \mathrm{GW}$ ) effect of reduction of efficiency even by $1 \%$ will also definitely have a significant effect.

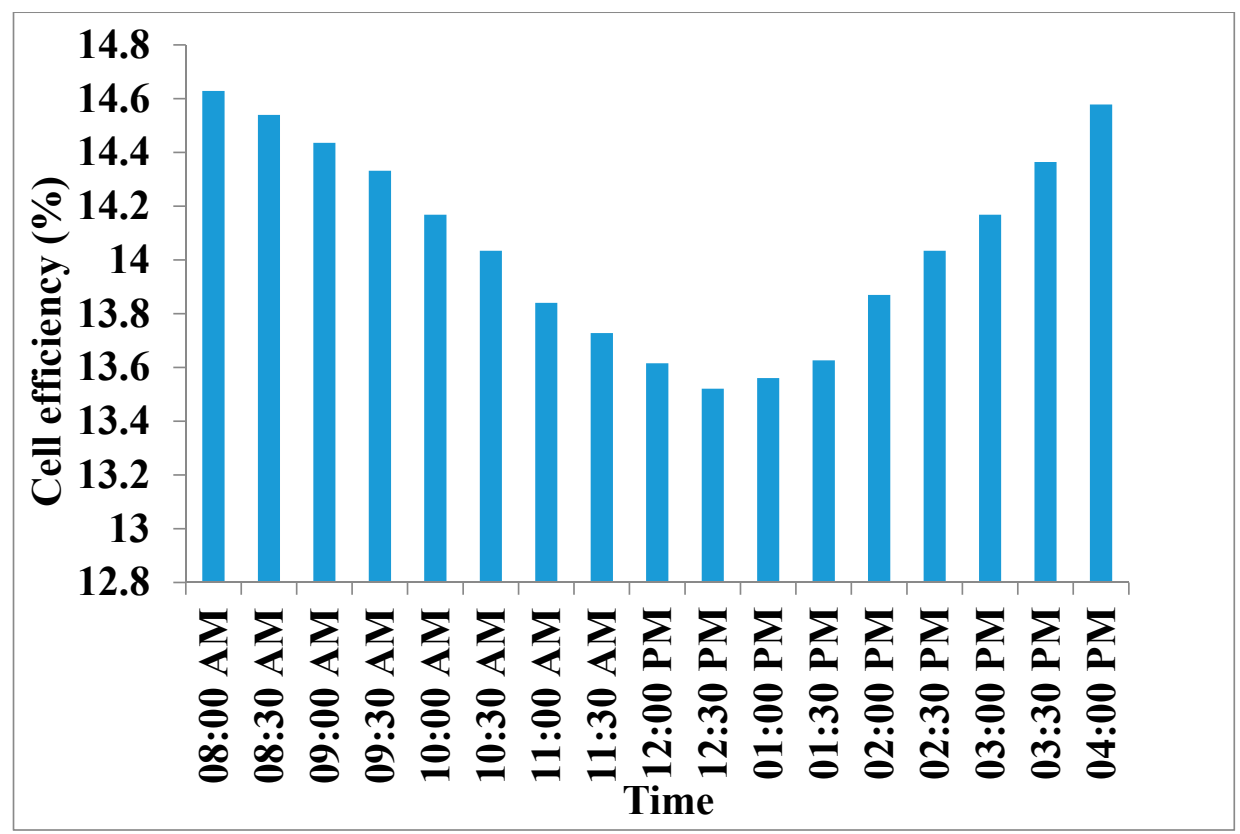

Figure 5. Variation of PV cell conversion efficiency of PVT system with time during the day, 15 May 2017. 
Figure 6 depicts the hourly variation of useful heat gain during the day. It is seen that the maximum heat gain is obtained at the noon time during peak solar radiation. Out of the total heat around $60.7 \%$ heat is contributed as the thermal heat and the remaining is equivalent electrical heat. Micro level analysis of results reveals that during noon time contribution of electrical heat attains a peak, decreases at either side. It is interesting to highlight here that even though cell efficiency decreased with increased solar radiation and the corresponding ambient temperature, but the electrical heat output is till high. This may be attributed to the availability of higher solar radiation.

Overall energy and exergy efficiency of solar photovoltaic thermal collector obtained by using Equations (5), (7) and (13) are presented in Figures 7 and 8, respectively. It is seen that energy efficiency increases with the increase in solar radiation, it attains the peak at the noon and it starts decreasing thereafter. It indicates the loss of energy remains almost constant throughout the day and the net useful energy increases with the increase in solar radiation. The exergy efficiency is found to be high in the morning and afternoon time, when the intensity of solar radiation is low. Maximum energy efficiency observed to be as high as $83 \%$ while the same for exergy efficiency is $16.6 \%$. Efficiency of PVT system is a summation electrical efficiency and thermal efficiency. On one hand, relatively lower value of energy efficiency of PVT system may be because of the lower conversion efficiency of photovoltaic system $(\sim 16 \%)$. On the other hand, lower value of exergy efficiency is mainly because of lower thermal exergy or lower useful thermal energy. Thus, to improve the overall performance of PVT system both quantity and quality of energy extracted by the PVT system has to be enhanced. And it can be achieved by increasing the production of electrical energy and by increasing the quality of thermal energy. To increase the thermal exergy or useful thermal energy preventive steps like surface modification may be done. Further, it is important to mention that, with increase in the solar radiation even though the thermal efficiency tends to increase, but the conversion efficiency of PV cell decreases. Thus, for a fully covered PVT system, considered in the present case, higher outlet air temperature from the collector $\left(T_{f o}\right)$ may also lead to reduction in electrical efficiency, especially from the PV cells present in the downstream of the collector.

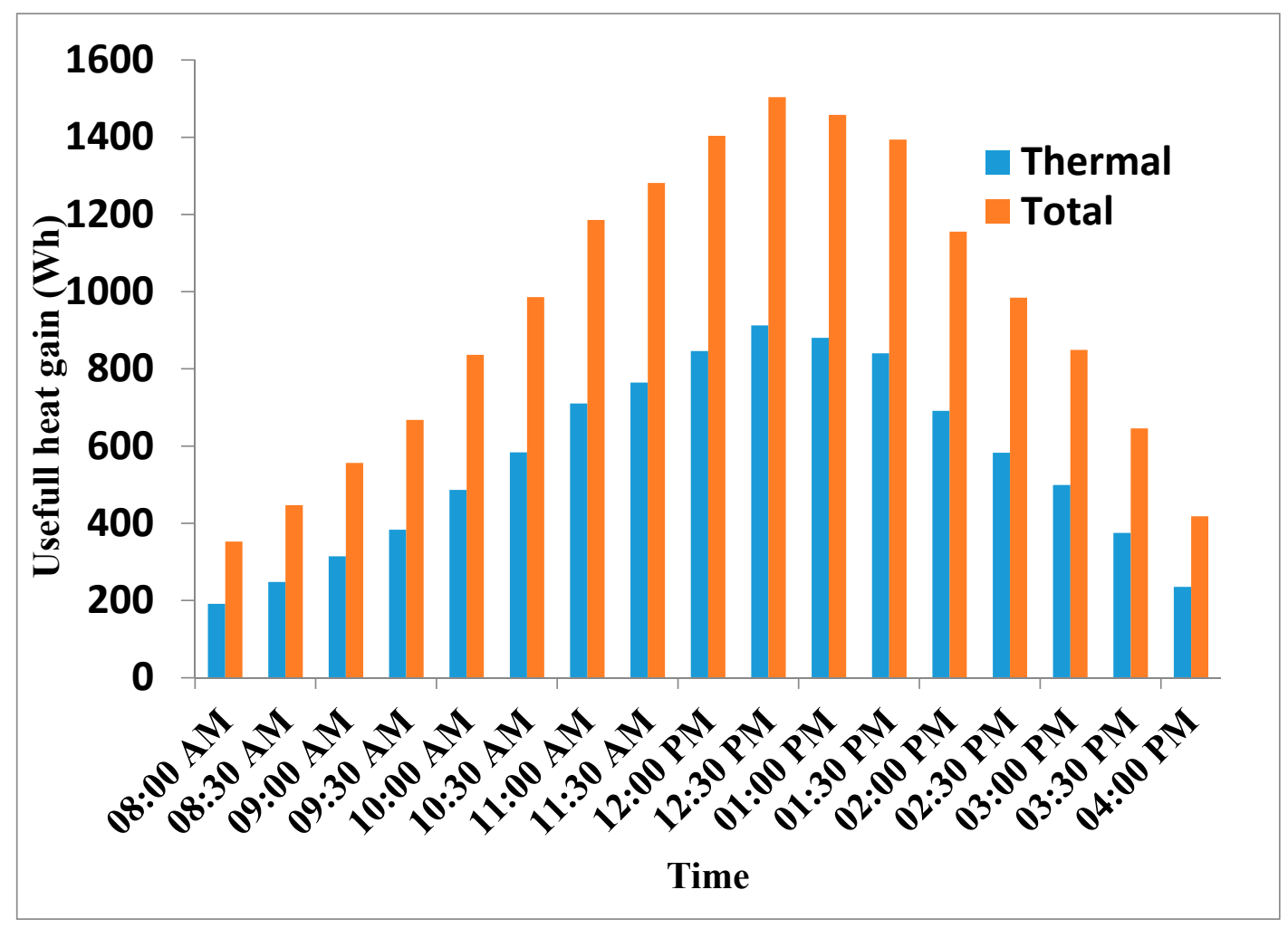

Figure 6. Variation of useful heat gain by the PVT system during the day, 15 May 2017. 


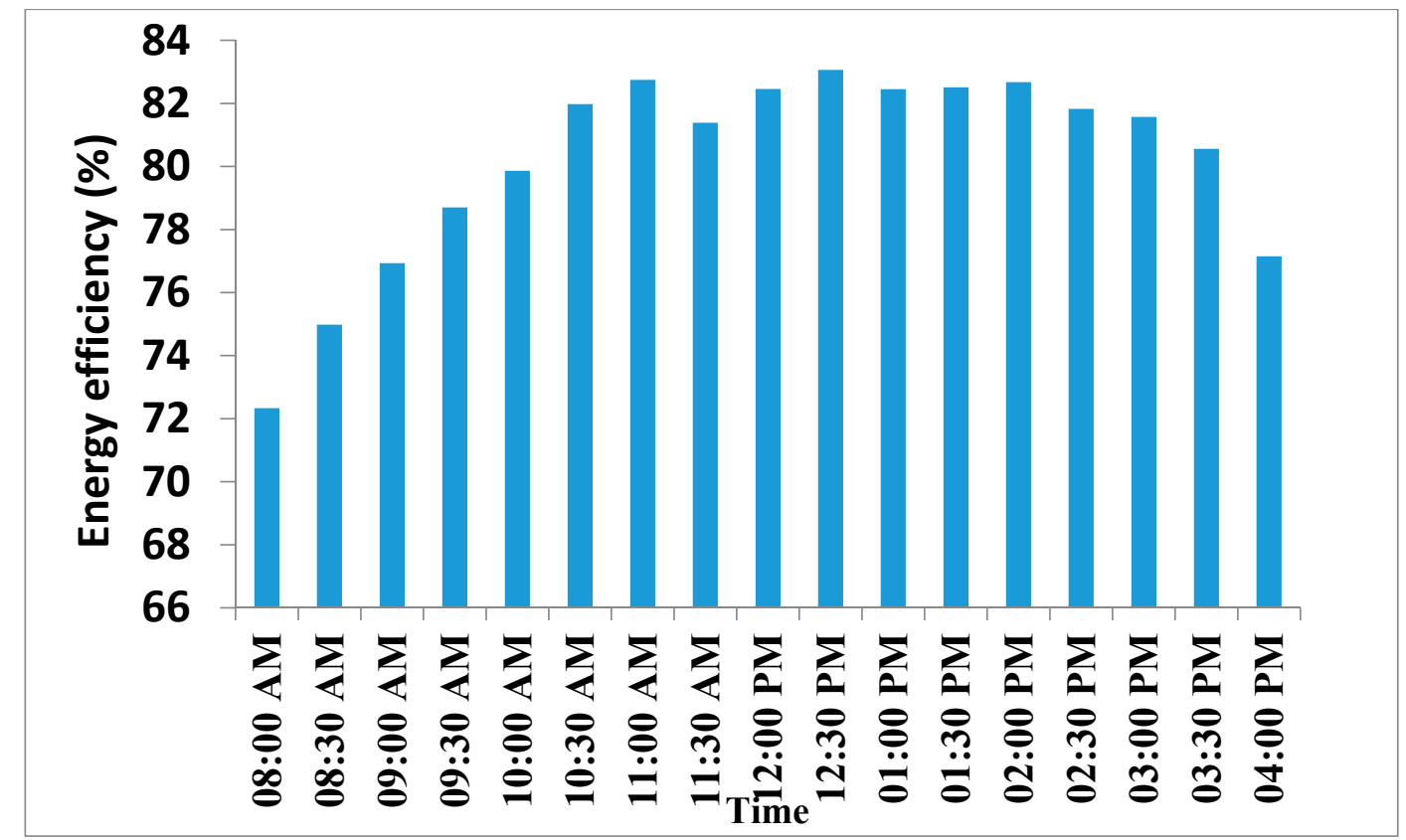

Figure 7. Variation of energy efficiency of PVT system with time.

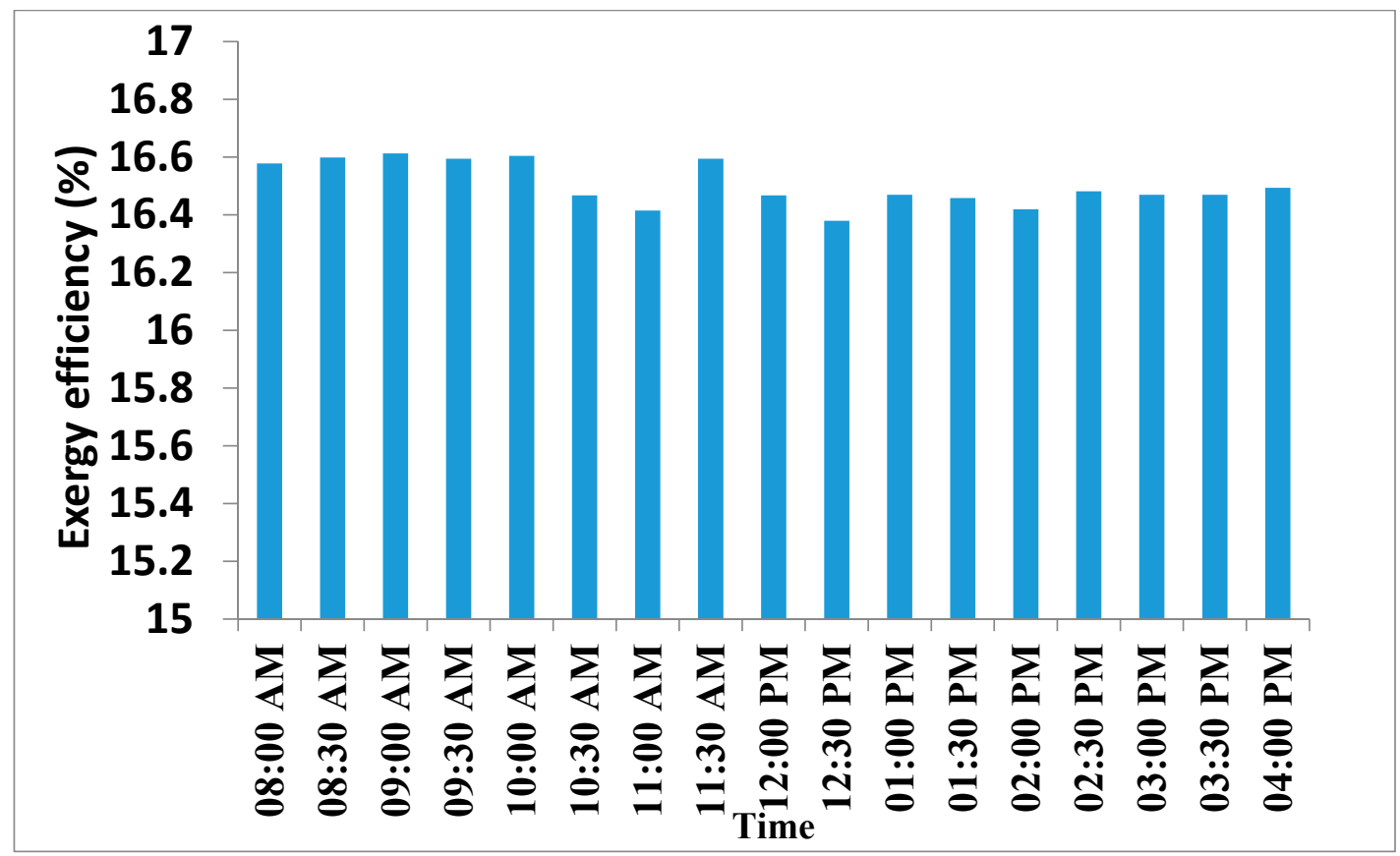

Figure 8. Variation of exergy efficiency of PVT system with time.

\section{Conclusions}

In the present study an analytical evaluation is made to evaluate the performance of single glazed solar PVT air system at the climatic condition of Silchar, NE India. Results unveil that efficiency of PV cell decreased with temperature, and a maximum conversion efficiency of PV cell found to be $14.6 \%$. At noon, maximum useful thermal heat output and maximum electrical heat output are found to be about $60.7 \%$, and $39.3 \%$, respectively. Maximum energy efficiency and maximum exergy efficiency are observed to be $83 \%$ and $16.6 \%$, respectively.

It is seen that with the increase in solar radiation total thermal output tends to increase, however, the electrical conversion efficiency tend to decrease. Thus, to improve the overall performance of PVT system proper steps may be taken to improve the electrical efficiency, and to enhance the thermal output of the collector. However, higher limit of the enhancement of thermal output is limited by the 
decrease in conversion efficiency of PV cell. Enhancement of thermal output may be achieved either of the two ways, first, having an option to increase the mass flow rate of working fluid during higher insolation, secondly choosing PVT system which is partially covered by PV panel. However, in both the ways practitioner need to compromise with one of the output, i.e., electrical output or hot working fluid.

It is important to mention here that the climatic condition considered here, i.e., Silchar comes under higher solar radiation zone, especially during the sunny day of May. Thus, a partially covered PVT system will give better results than the considered fully covered PVT system. However, during the winter season (in the month of November-January) even the fully covered PVT system will also give better performance as the intensity of solar radiation is comparatively lower. Further, it also indicates that it is necessary to perform the tests of PVT system for all the possible climatic condition before finalizing the design.

Thus, from the present energy and exergy analysis of PVT system finally it may be concluded that requirement basis design of a PVT system is more useful to make a trade-off between electrical output and thermal output.

Acknowledgment: One of the authors sincerely acknowledges the fund received under BASE fellowship from DST, GoI and IUSSTF.

\section{Abbreviations}

The following abbreviations are used in this manuscript

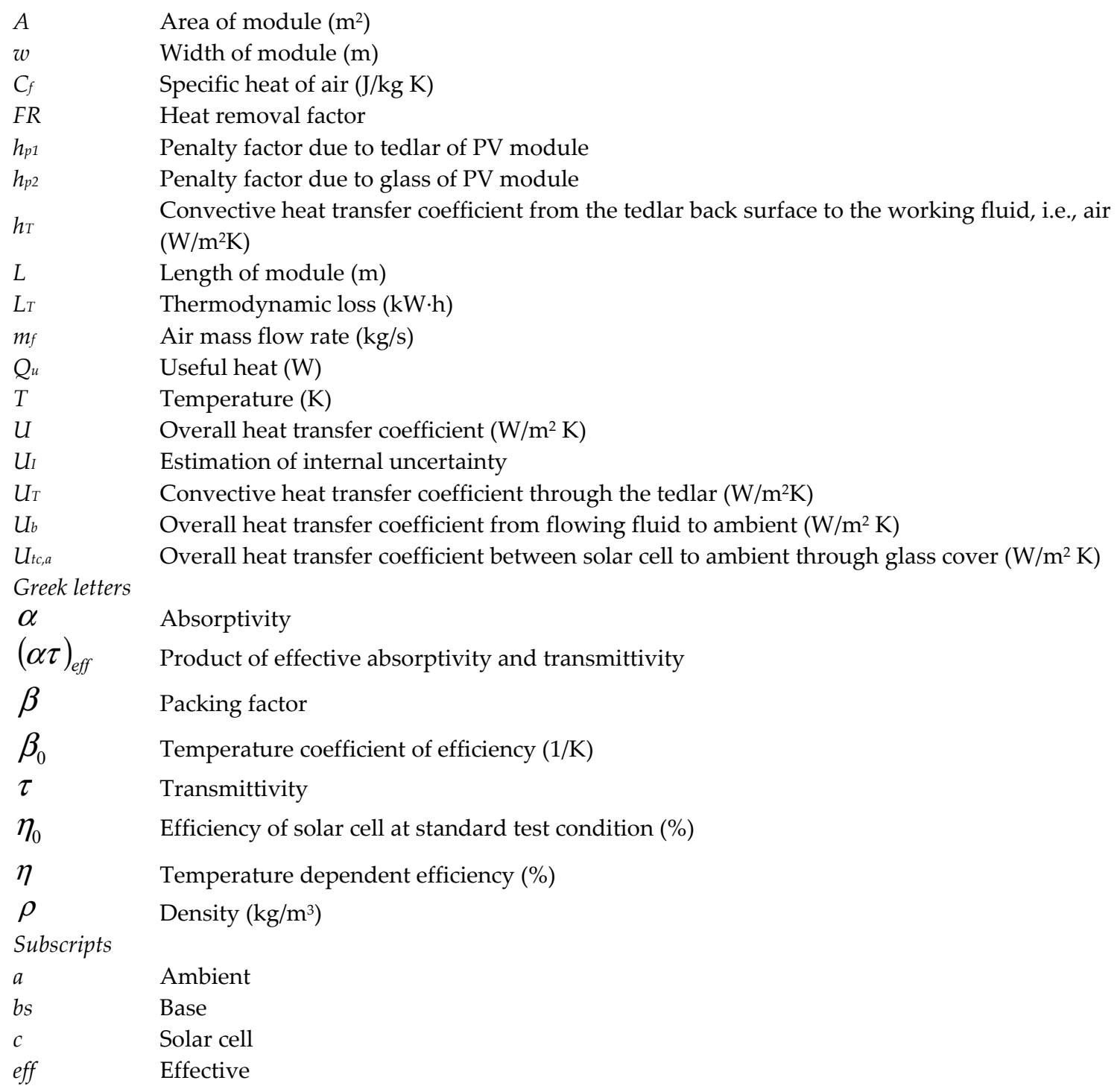




$\begin{array}{ll}f & \text { Fluid (air) } \\ f i & \text { Inlet fluid } \\ f o & \text { Outgoing fluid } \\ g & \text { Glass } \\ s & \text { Sun } \\ T & \text { Tedlar } \\ t c & \text { Tedlar to cell }\end{array}$

\section{References}

1. Sahota, L.; Tiwari, G.N. Review on series connected photovoltaic thermal (PVT) systems: Analytical and experimental studies. Sol. Energy 2017, 150, 96-127.

2. Bhargava, A.K.; Garg, H.P.; Agrawal, R.K. Study of a hybrid solar system-solar air heater combined with solar cells. Energy Convers. Manag. 1991, 31, 471-479.

3. Sopian, K.; Yigit, K.S.; Liu, H.T.; Kakaç, S.; Veziroglu, T.N. Performance analysis of photovoltaic thermal air heaters. Energy Convers. Manag. 1996, 37, 1657-1670.

4. Garg, H.P.; Adhikari, R.S. Conventional hybrid photovoltaic/thermal (PV/T) air heating collectors: Steadystate simulation. Renew. Energy 1997, 11, 363-385.

5. Hegazy, A.A. Comparative study of the performances of four photovoltaic/thermal solar air collectors. Energy Convers. Manag. 2000, 41, 861-881.

6. Othman, M.Y.H.; Ruslan, H.; Sopian, K.; Jin, G.L. Performance study of photovoltaic-thermal (PV/T) solar collector with del-grooved absorber plate. Sains Malays. 2009, 38, 537-541.

7. Kim, J.H.; Kim, J.T. Comparison of Electrical and Thermal Performances of Glazed and Unglazed PVT Collectors. Int. J. Photoenergy 2012, doi:10.1155/2012/957847.

8. Tonui, J.K.; Tripanagnostopoulos, Y. Air-cooled PVT solar collectors with low-cost performance improvements. Sol. Energy 2007, 81, 498-511.

9. Raman, V.; Tiwari, G.N. Life cycle cost analysis of HPVT air collector under different Indian climatic conditions. Energy Policy 2008, 36, 603-611.

10. Dubey, S.; Sandhu, G.S.; Tiwari, G.N. Analytical expression for electrical efficiency of PV/T hybrid air collector. Appl. Energy 2009, 86, 697-705.

11. Farshchimonfared, M.; Bilbao, J.I.; Sproul, A.B. Full optimisation and sensitivity analysis of a photovoltaic-Thermal (PV/T) air system linked to a typical residential building. Sol. Energy 2016, 136, 15-22.

12. Sarhaddi, F.; Farahat, S.; Ajam, H.; Behzadmehr, A.; Adeli, M.M. An improved thermal and electrical model for a solar photovoltaic thermal (PV/T) air collector. Appl. Energy 2010, 87, 2328-2339.

13. Agrawal, S.; Tiwari, A. Experimental validation of micro-channel solar cell thermal tile. Sol. Energy 2011, 85, 3046-3056.

14. Hussain, F.; Othman, M.Y.H.; Yatim, B.; Ruslan, H.; Sopian, K.; Anuar, Z.; Khairuddin, S. An improved design of photovoltaic/thermal solar collector. Sol. Energy 2015, 122, 885-891.

15. Khelifa, A.; Touafek, K.; BenMoussa, H.; Tabet, I.; Bencheikh, H.; Haloui, H. Analysis of a hybrid solar collector photovoltaic thermal (PVT). Energy Procedia 2015, 74, 835-843.

16. Yang, T.; Athienitis, A.K. Experimental investigation of a two-inlet air-based building integrated photovoltaic/thermal (BIPV/T) system. Appl. Energy 2015, 159, 70-79.

17. Pauly, L.; Rekha, L.; Vazhappilly, C.V.; Melvinraj, C.R. Numerical Simulation for Solar Hybrid Photovoltaic Thermal Air Collector. Procedia Technol. 2016, 24, 513-522.

18. Mojumder, J.C.; Chong, W.T.; Ong, H.W.; Leong, K.Y.; Mamoon, A.A. An experimental investigation on performance analysis of air type photovoltaic thermal collector system integrated with cooling fins design. Energy Build. 2016, 130, 272-285.

19. Dimri, N.; Tiwari, A.; Tiwari, G.N. Thermal modelling of semitransparent photovoltaic thermal (PVT) with thermoelectric cooler (TEC) collector. Energy Convers. Manag. 2017, 146, 68-77.

20. Ooshaksaraei, P.; Sopian, K.; Zaidi, S H.; Zulkifli, R. Performance of four air-based photovoltaic thermal collectors configurations with bifacial solar cells. Renew. Energy 2017, 102, 279-293.

21. Slimani, M.; Amirat, M.; Kurucz, I.; Bahria, S.; Hamidat, A.; Chaouch, W.B. A detailed thermal-electrical model of three photovoltaic/thermal (PV/T) hybrid air collectors and photovoltaic (PV) module: Comparative study under Algiers climatic conditions. Energy Convers. Manag. 2017, 133, 458-476. 
22. Kamthania, D.; Nayak, S.; Tiwari, G.N. Energy and exergy analysis of a hybrid photovoltaic thermal double pass air collector. Appl. Sol. Energy 2011, 47, 199-206.

23. Agrawal, S.; Tiwari, A. Overall energy, exergy, and carbon credit analysis by different types of hybrid photovoltaic thermal air collectors. Energy Convers. Manag. 2013, 65, 628-636.

24. Dubey, S.; Tiwari, G.N. Energy and exergy analysis of different configuration of flat plate collectors connected in series. Int. J. Energy Res. 2009, 32, 1362-1372.

25. Agrawal, S.; Tiwari, G.N. Exergoeconomic analysis of glazed hybrid photovoltaic thermal module air collector. Sol. Energy 2012, 86, 2826-2838.

26. Agrawal, S.; Tiwari, A. Energy and exergy analysis of hybrid micro-channel photovoltaic thermal module. Sol. Energy 2011, 85,356-370.

27. Bahrehmand, D.; Ameri, M.; Gholampour, M. Energy and exergy analysis of different solar air collector systems with forced convection. Renew. Energy 2015, 83, 1119-1130.

(C) 2018 by the authors. Licensee MDPI, Basel, Switzerland. This article is an open access article distributed under the terms and conditions of the Creative Commons Attribution (CC BY) license (http://creativecommons.org/licenses/by/4.0/). 